\title{
Regulation of $d s r$ genes encoding proteins responsible for the oxidation of stored sulfur in Allochromatium vinosum
}

\author{
Frauke Grimm, Nadine Doblert and Christiane Dahl
}

Correspondence

Christiane Dahl

chdahl@uni-bonn.de

Received 15 September 2009

Revised 23 November 2009

Accepted 8 December 2009

\author{
Institut für Mikrobiologie \& Biotechnologie, Rheinische Friedrich-Wilhelms-Universität Bonn, \\ Meckenheimer Allee 168, D-53115 Bonn, Germany
}

\begin{abstract}
Sulfur globules are formed as obligatory intermediates during the oxidation of reduced sulfur compounds in many environmentally important photo- and chemolithoautotrophic bacteria. It is well established that the so-called Dsr proteins are essential for the oxidation of zero-valent sulfur accumulated in the globules; however, hardly anything is known about the regulation of dsr gene expression. Here, we present a closer look at the regulation of the $d s r$ genes in the phototrophic sulfur bacterium Allochromatium vinosum. The $d s r$ genes are expressed in a reduced sulfur compound-dependent manner and neither sulfite, the product of the reverse-acting dissimilatory sulfite reductase DsrAB, nor the alternative electron donor malate inhibit the gene expression. Moreover, we show the oxidation of sulfur to sulfite to be the rate-limiting step in the oxidation of sulfur to sulfate as sulfate production starts concomitantly with the upregulation of the expression of the $d s r$ genes. Real-time RT-PCR experiments suggest that the genes $d s r C$ and $d s r S$ are additionally expressed from secondary internal promoters, pointing to a special function of the encoded proteins. Earlier structural analyses indicated the presence of a helix-turn-helix (HTH)like motif in DsrC. We therefore assessed the DNA-binding capability of the protein and provide evidence for a possible regulatory function of DsrC.
\end{abstract}

\section{INTRODUCTION}

Reduced sulfur compounds are utilized as electron donors by a large and diverse group of prokaryotes. Many sulfuroxidizing bacteria accumulate globules of polymeric, water-insoluble sulfur as an intermediary product during sulfur oxidation. These sulfur globules are either deposited extracellularly (Chlorobiaceae, Ectothiorhodospiraceae, some thiobacilli) or intracellularly, inside the periplasm [Chromatiaceae, Beggiatoa species, endosymbionts of marine invertebrates like Riftia pachyptila and Calyptogena okutanii (Dahl \& Prange, 2006)]. The best-studied enzyme system responsible for the oxidation of sulfur globules is encoded by the dissimilatory sulfite reductase $(d s r)$ genes, dsrABEFHCMKLJOPNRS, of the anoxygenic phototrophic purple sulfur bacterium Allochromatium vinosum (Dahl, 2008; Grimm et al., 2008; Sander \& Dahl, 2009; Frigaard \& Dahl, 2009). The cytoplasmic dissimilatory sulfite reductase, encoded by $d s r A B$, is homologous to the sulfite reductase of sulfate-reducing prokaryotes (Loy et al., 2009). The latter enzyme is indispensable for reduction of sulfite to sulfide in sulfate reducers.

†Present address: Forschungszentrum Jülich, Institut für Biotechnologie 1, D-52425 Jülich, Germany.

Supplementary tables of strains, plasmids and primers are available with the online version of this paper.
In sulfur-oxidizing bacteria, the enzyme is thought to operate in the reverse direction (Schedel \& Trüper, 1979; Schedel et al., 1979). As A. vinosum is a member of the Chromatiaceae, sulfur globules are stored in the periplasm. The sulfur is assumed to be reductively activated and transported into the cytoplasm via a perthiolic organic carrier molecule. Sulfide could then be released from the carrier and might be transferred to DsrAB via a sulfur relay system involving the proteins DsrEFH and DsrC. Electrons released from the oxidation might be fed into the photosynthetic electron transport via DsrMKJOP, a transmembrane redox complex. DsrN probably catalyses the glutamine-dependent amidation of sirohaem, the cofactor of DsrAB. The function of DsrL, DsrR and DsrS is not resolved, but in-frame deletion proved DsrL to be essential for sulfur oxidation (Pott \& Dahl, 1998; Dahl et al., 2005; Sander et al., 2006; Lübbe et al., 2006; Cort et al., 2008; Dahl et al., 2008).

After the first description of the $d s r$ operon, research focused on substrate delivery and electron flow during sulfur oxidation. Regulatory aspects were of secondary interest and proteins involved therein have not yet been identified. The protein DsrC appears to be a candidate, as the NMR structures of the proteins from the sulfurreducing archaeon Pyrobaculum aerophilum and also from A. vinosum revealed a possible DNA-binding motif (Cort et al., 2001, 2008). To date, the proposed DNA-binding 
ability of DsrC has not been further examined. In this report we present insights into the regulation of the $d s r$ operon in A. vinosum. To this end, we investigated the expression of $d s r$ genes via reporter gene fusions and absolute quantitative real-time RT-PCR. In addition, we attempted to identify potential regulatory proteins and assessed the potential DNA-binding activity of DsrC via DNA mobility shift assays.

\section{METHODS}

Construction of transcriptional and translational gene fusion plasmids. All general molecular genetic techniques and bacterial growth conditions were described earlier (Dahl et al., 2008). A detailed description of all the bacterial strains and plasmids (Supplementary Table S1) and primer sequences (Supplementary Table S2) used can be found in the online supplementary material. A 908 bp DNA fragment encompassing the $d s r$ promoter $d s r A_{\mathrm{P}}$, not including the ribosome-binding site of $d s r A$, was amplified by PCR introducing EcoRI and PstI restriction sites via modified primers. A. vinosum Rif50 chromosomal DNA served as template. The EcoRI/ PstI-digested fragment was inserted into pK18mobsacB (Schäfer et al., 1994), yielding pKdsrProm. The lac $Z$ gene, including the RBS, was amplified using Escherichia coli K-12 DNA. PstI and HindIII restriction sites were introduced via modified primers. The amplicon was digested and ligated to the $6560 \mathrm{bp}$ PstI/HindIII fragment of pKdsrProm, resulting in the $d s r A_{\mathrm{p}}-l a c Z$ transcriptional fusion plasmid pTS. The promoterless lacZ gene was excised by SalI and EcoRI from the translational lacZ fusion vector pPHU235 (Hübner et al., 1991). The SalI site was filled with the Klenow fragment of DNA polymerase. The fragment was inserted into the $5670 \mathrm{bp}$ EcoRI/HindIII fragment of pK18mobsacB, yielding the plasmid pK235 (Bettina Franz, personal communication). The $d s r$ promoter region, including the first $12 \mathrm{bp}$ of $d s r A$, was amplified using primers that introduced PstI and HindIII restriction sites, respectively. The fragment was inserted into pK235, resulting in the $d s r A^{\prime}$-lacZ translational fusion plasmid pTL.

Growth experiments and $\boldsymbol{\beta}$-galactosidase assay. The gene fusion plasmids were conjugatively transferred into $A$. vinosum Rif50 as described by Pattaragulwanit \& Dahl (1995) and integrated into the genome via single-crossover. The plasmid-carrying strains were grown in $12 \mathrm{ml}$ modified Pfennig's medium (Dahl et al., 2008) with $2 \mathrm{mM}$ thiosulfate, sulfide, and/or sulfite, and/or malate for $24 \mathrm{~h}$ before $\beta$-galactosidase activity was tested. A $1 \mathrm{ml}$ culture sample was pelleted $\left(13000 \mathrm{~g}, 3 \mathrm{~min}, 4{ }^{\circ} \mathrm{C}\right)$ and resuspended in $1 \mathrm{ml} \mathrm{Z}$ buffer (Miller, 1972). After the addition of $100 \mu \mathrm{l}$ chloroform and $50 \mu \mathrm{l}$ $0.1 \%(\mathrm{w} / \mathrm{v})$ SDS, the sample was vortexed for $10 \mathrm{~s}$ at maximum speed and incubated at $30{ }^{\circ} \mathrm{C}$ for $10 \mathrm{~min}$ before $200 \mu \mathrm{l}$ preheated $4 \mathrm{mg}$ ONPG $\mathrm{ml}^{-1}$ was added. As soon as a yellow colour could be discerned, the reaction was stopped by adding $500 \mu 11 \mathrm{M} \mathrm{Na}_{2} \mathrm{CO}_{3}$. After centrifugation $(15000 \mathrm{~g}, 5 \mathrm{~min})$ the absorbance of the supernatant was measured in a $1 \mathrm{ml}$ quartz cuvette (path length $1 \mathrm{~cm})$ at $460 \mathrm{~nm}$ against a chemical blank in a GENESYS 20 spectrometer (Thermo). The specific $\beta$-galactosidase activity was calculated by using the following formula: [nmol $o$-nitrophenol $\left.\min ^{-1}(\operatorname{mg} \text { protein })^{-1}\right]=\left[\left(A_{420} \times k^{-1}\right) \times V_{\text {assay }}(\mathrm{ml})\right] /\left[t_{\text {assay }}(\min ) \times\right.$ protein concentration $\left.\left(\mathrm{mg} \mathrm{ml}^{-1}\right) \times V_{\text {culture }}(\mathrm{ml})\right]$. Under the above conditions $1 \mu \mathrm{M} o$-nitrophenol had an $A_{420}$ of $0.0044(k)$. The protein concentration for each sample was determined by Bradford assay (Bradford, 1976). Wild-type A. vinosum did not exhibit any $\beta$ galactosidase activity. The time-course of $d s r A$ expression during sulfur oxidation was examined in batch culture under continuous illumination as described by Prange et al. (2004): $250 \mathrm{ml}$ of a heterotrophically grown stationary-phase culture was harvested and the cell material was used to inoculate 11 of modified Pfennig's medium in a thermostatted fermenter. $\beta$-Galactosidase activity was measured immediately after taking a sample. Sulfur compounds were determined as described by Dahl et al. (2008).

Expression studies by real-time RT-PCR. Total RNA of $A$. vinosum strains Rif50 and 21D (Pott \& Dahl, 1998; Dahl et al., 2005), grown under photoorganoheterotrophic or sulfide-oxidizing conditions, was isolated and quantified as described by Prange et al. (2004). RNA samples of $250 \mathrm{ng}$ were used for real-time RT-PCR analysis utilizing the QuantiTect SYBR Green RT-PCR kit (Qiagen) and the iCycler iQ real-time detection system (Bio-Rad) according to the manufacturers' instructions. 'No-RT' control reactions were performed for each RNA sample. In case of DNA contamination, the RNA samples were digested with RNase-free DNase (Qiagen) and purified using the RNeasy Mini kit (Qiagen). Approximately $200 \mathrm{bp}$ fragments of $d s r A\left(T_{\mathrm{a}} 59^{\circ} \mathrm{C}\right), d s r E\left(T_{\mathrm{a}} 56{ }^{\circ} \mathrm{C}\right), d s r C\left(T_{\mathrm{a}} 55{ }^{\circ} \mathrm{C}\right), d s r L$ $\left(T_{\mathrm{a}} 57^{\circ} \mathrm{C}\right), d s r R\left(T_{\mathrm{a}} 60{ }^{\circ} \mathrm{C}\right)$ and $d s r S\left(T_{\mathrm{a}} 58{ }^{\circ} \mathrm{C}\right)$ were amplified, utilizing the indicated annealing temperature $\left(T_{\mathrm{a}}\right)$. The RT-PCR conditions were as follows: $30 \mathrm{~min}$ at $50{ }^{\circ} \mathrm{C}$ (reverse transcription), $15 \mathrm{~min}$ at $95{ }^{\circ} \mathrm{C}$ (inactivation of the reverse transcriptase and activation of the polymerase), 40 cycles of $15 \mathrm{~s}$ at $94{ }^{\circ} \mathrm{C}, 30 \mathrm{~s}$ at $T_{\mathrm{a}}$ and $30 \mathrm{~s}$ at $72{ }^{\circ} \mathrm{C}$, followed by melting-curve analysis in which the temperature was increased every $30 \mathrm{~s}$ by $0.5^{\circ} \mathrm{C}$, starting at $40{ }^{\circ} \mathrm{C}$, to $100{ }^{\circ} \mathrm{C}$. PCR products were examined by agarose gel electrophoresis. RNA standards were generated as described by Fey et al. (2004). The samples were automatically quantified by the iCycler iQ software (Bio-Rad) based on the RNA standards.

Cloning and sequencing of the dsr upstream region and inframe deletion of orfB and orfC. A PCR-amplified fragment representing the published $d s r$ operon sequence from nucleotides 62 to 484 was used as a probe to identify positive clones with a $3.1 \mathrm{~kb}$ $\mathrm{NcoI}$ insert in a library of 2.8-3.4 kb NcoI fragments of chromosomal A. vinosum DNA in the vector pGEM-5Zf(-). Sequencing of the positive clone pGem53000 yielded a 3099 bp sequence, including $2321 \mathrm{bp}$ of new sequence. The double-stranded DNA was sequenced by Sequiserve (Vaterstetten, Germany). Sequence analyses were carried out essentially as described by Dahl et al. (2005). In-frame deletions of $\operatorname{orf} B$ and $\operatorname{orf} C$ were constructed as described by Lübbe et al. (2006). Photolithoautotrophic growth of A. vinosum wild-type and mutant strains was examined as described above for the strains carrying gene fusion plasmids.

GenBank accession number. The genome sequence of $A$. vinosum DSM 180 has been submitted to GenBank and is available under accession no. ACQQ00000000.

DNA mobility shift assay. A $942 \mathrm{bp}$ fragment of the $d s r$ promoter region was obtained by PCR utilizing A. vinosum Rif50 DNA as template. The amplicon was cleaved by EcoRV or XhoI. The $d s r$ promoter region or fragments $(200 \mathrm{fmol})$ were incubated with DsrC (0-500 pmol) [overproduced and purified as described by Dahl et al. (2005)] in incubation buffer [5 mM HEPES pH 7.8, $20 \mathrm{mM} \mathrm{KCl}$, $0.02 \%$ o (v/v) Tween 20 and $1 \mathrm{mM} \mathrm{TCEP]} \mathrm{for} 15 \mathrm{~min}$ at room temperature. The samples were transferred to a $2 \%$ agarose gel in $0.5 \times$ TBE buffer. Following electrophoresis $(90 \mathrm{~V})$ the gel was dyed with $10 \mathrm{mg}$ ethidium bromide $\mathrm{l}^{-1}$ and analysed under UV light. A fragment of the kanamycin-resistance gene $(200 \mathrm{fmol})$ of plasmid pK18mobsacB was incubated together with the promoter region and $\mathrm{DsrC}$ as non-specific competitor. The online version of the program REPuter (http://bibiserv.techfak.uni-bielefeld.de/reputer) was used for detection of inverted or direct repeats in the nucleotide sequence upstream of $d s r A$. Promoter prediction for prokaryotic sequence was achieved with Neural Network Promoter Prediction (http://www. fruitfly.org/seq_tools/promoter.html) and BPROM (http://www. softberry.com/berry.phtml). 


\section{RESULTS}

\section{Expression of dsrA is enhanced under sulfur- oxidizing conditions}

We examined the expression of the $d s r A$ gene in wild-type $A$. vinosum under photoorganoheterotrophic and photolithoautotrophic growth conditions. The transcription of the $d s r A$ gene was measured by fusing the $d s r$ promoter $d s r A_{\mathrm{P}}$ to $l a c Z$. A $d s r A^{\prime}-l a c Z$ gene fusion, where both transcription and translation of the lac $Z$ gene were dependent upon $d s r A$ gene expression, was used to determine the translation of the gene. In the case of the transcriptional gene fusion, $\beta$ galactosidase activities were low in malate-grown cells and three times higher under sulfur-oxidizing conditions (Table 1). A similar degree of increase was observed for the activities of the translational fusion. When thiosulfate was used as electron donor the same degree of increase was observed as for sulfide. As essentially the same expression patterns were observed for the translational gene fusion and for the transcriptional fusion, regulation at the post-transcriptional level appears not to have a major influence on the production of DsrA. Nevertheless, the $\beta$-galactosidase activities were roughly ten times higher for the translational fusion than for the transcriptional fusion, demonstrating the importance of the native ribosome-binding site for the expression of $d s r A$ in A. vinosum. All subsequent experiments were performed with the DsrA'-LacZ fusion.

\section{Sulfide does not directly induce dsrA expression}

A time-course of $\beta$-galactosidase activity during sulfide oxidation was examined in a $1 \mathrm{l}$ batch culture with $2 \mathrm{mM}$

Table 1. Expression of transcriptional and translational gene fusions

\begin{tabular}{|c|c|c|}
\hline \multirow[t]{2}{*}{ Electron source ${ }^{\star}$} & \multicolumn{2}{|c|}{ Specific $\beta$-galactosidase activity $\dagger$} \\
\hline & $d s r A_{\mathrm{P}}-l a c Z$ & $d s r A^{\prime}-l a c Z$ \\
\hline Malate & $2.9 \pm 0.7$ & $42.6 \pm 1.7$ \\
\hline Sulfide & $9.1 \pm 0.9$ & $96.2 \pm 27.1$ \\
\hline Thiosulfate & ND & $89.5 \pm 9.4$ \\
\hline Malate + sulfide & ND & $96.4 \pm 10.5$ \\
\hline Sulfite & ND & $39.0 \pm 7.4$ \\
\hline Sulfite + sulfide & ND & $94.3 \pm 30.9$ \\
\hline
\end{tabular}

ND, Not determined.

*Modified Pfennig's medium containing $2 \mathrm{mM}$ of the indicated electron source was inoculated with photoorganoheterotrophically grown cultures, containing transcriptional $\left(d s r A_{\mathrm{p}}\right.$-lac $\left.Z\right)$ or translational $\left(d s r A^{\prime}\right.$-lac $\left.Z\right)$ gene fusion plasmids. The $\beta$-galactosidase activity was measured $24 \mathrm{~h}$ after inoculation.

$\dagger$ The specific $\beta$-galactosidase activity is given as nmol $o$-nitrophenol $\min ^{-1}$ (mg protein $)^{-1}$. The average protein content was $500 \mu \mathrm{g} \mathrm{ml}^{-1}$. The results represent the means and standard deviations of three independent measurements. sulfide under controlled conditions (Fig. 1). As expected for the purple sulfur bacterium A. vinosum, sulfide was immediately metabolized and intracellular sulfur globules were formed. The stored sulfur was further metabolized to the end product sulfate. The $\beta$-galactosidase activities started at a low level and increased significantly after sulfide had been almost completely oxidized and sulfur globules had been formed. Therefore, we concluded that sulfide itself does not directly induce $d s r A$ expression. $\beta$ Galactosidase activities increased simultaneously with sulfate production. Apparently, the oxidation of stored sulfur to sulfite is the rate-limiting step during the oxidation of sulfur to sulfate. Sulfite was not detected during sulfur oxidation.

The influence of the initial concentration of sulfide on the expression level of $d s r A$ was examined in $12 \mathrm{ml}$ cultures. Higher sulfide concentrations led to higher $\beta$-galactosidase activities (Fig. 2). The expression level of $d s r A$ is dependent on the strength of the inducing signal.

\section{Expression of dsrA is not inhibited by malate or sulfite}

A. vinosum is able to use organic compounds as alternative photosynthetic electron donors (Fuller et al., 1961; Pfennig \& Trüper, 1989). Therefore, the question arose whether the expression of $d s r A$ would be inhibited by the presence of an organic electron donor like malate. We incubated the translational reporter strain on malate- and sulfide-

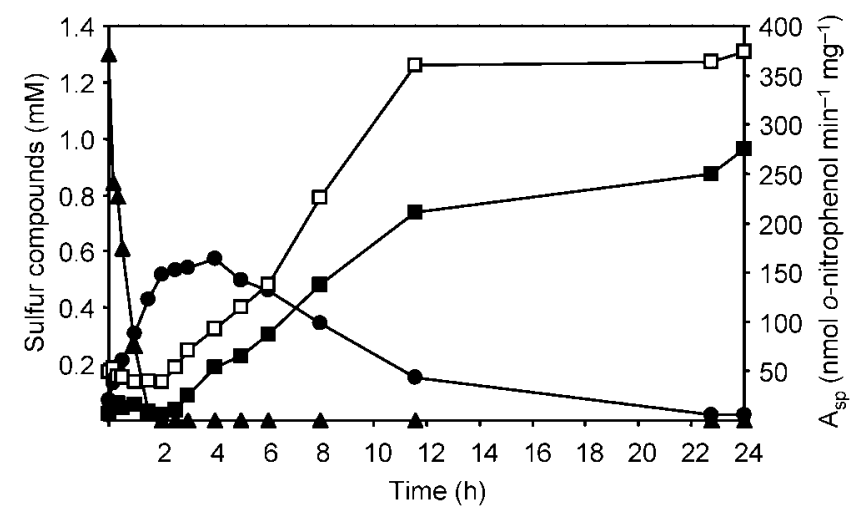

Fig. 1. Time-course of $d s r A^{\prime}-l a c Z$ expression under sulfuroxidizing conditions. The oxidation of sulfide $(\boldsymbol{\Lambda})$, formation and degradation of sulfur ( $)$, production of sulfate ( $\boldsymbol{\square})$ and expression of $d s r A^{\prime}-l a c Z(\square)$ were examined in a thermostatted fermenter with modified Pfennig's medium containing $2 \mathrm{mM}$ sulfide. Sulfide could not be completely recovered as sulfate due to loss of gaseous $\mathrm{H}_{2} \mathrm{~S}$ during sampling (Pott \& Dahl, 1998). The high specific $\beta$-galactosidase activities were due to the optimized conditions under which the culture was grown. The protein content was $84 \mu \mathrm{g} \mathrm{ml}^{-1}$ at the onset of the experiment and $106 \mu \mathrm{g} \mathrm{ml}^{-1}$ at the end. A representative of two independent experiments is shown. 


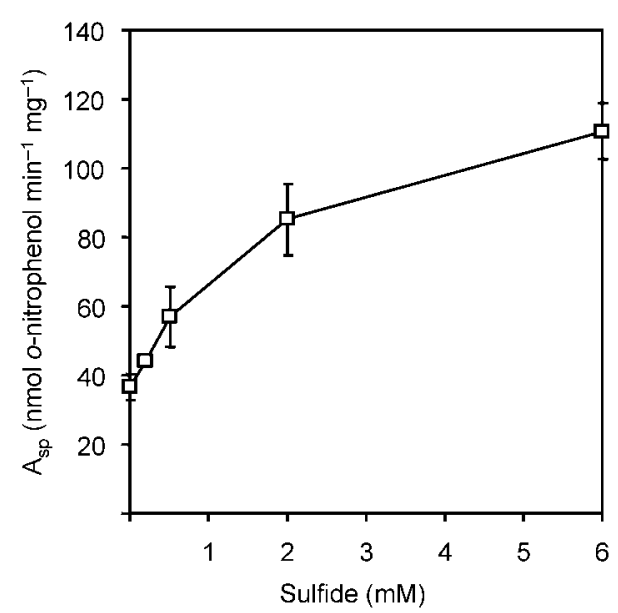

Fig. 2. Influence of the concentration of sulfide on the expression level of DsrA'-LacZ. Photoorganoheterotrophically grown $A$. vinosum cultures containing the translational gene fusion plasmid were incubated for $24 \mathrm{~h}$ in modified Pfennig's medium with different concentrations of sulfide. The average protein content was $500 \mu \mathrm{g} \mathrm{ml}^{-1}$. The results represent the means and standard deviations of three independent measurements.

containing medium and examined the $\beta$-galactosidase activity in comparison to cultures grown on either malate or sulfide alone (Table 1). The 'malate and sulfide'-grown cells showed the same level of activity as sulfide-grown cells, indicating that the presence of malate had no influence on the expression of $d s r A$.

Sulfite is the proposed product of the reaction catalysed by reverse-acting sulfite reductase (Schedel \& Trüper, 1979; Schedel et al., 1979; Frigaard \& Dahl, 2009). As such, sulfite could affect the expression of the sulfite reductaseencoding genes $d s r A B$. However, when sulfite was added to the medium, $\beta$-galactosidase activity did not decrease compared to the activity exhibited under photoorganotrophic conditions (Table 1). Comparison of the specific $\beta$ galactosidase activities of cells grown on sulfite and sulfide with those of cells grown on sulfide alone showed the activities to be virtually identical. Clearly, sulfite cannot inhibit the expression of $d s r A$ in A. vinosum.

\section{Regulation of dsrA, $L$ and $R$ differs from that of dsrE, $C$ and $S$}

In an effort to examine and compare the transcription pattern of several $d s r$ genes, we performed absolute quantitative real-time RT-PCR. We specifically chose genes $(d s r E, d s r C, d s r L, d s r R$ and $d s r S)$ that encode proteins of uncertain function and therefore could play a role in the regulation of the operon. Total RNA was isolated from malate- or sulfide-grown cultures of wild-type A. vinosum and the mutant 21D (Pott \& Dahl, 1998; Dahl et al., 2005). The latter carries an insertion of a kanamycin $\Omega$ interposon in $d s r B$, leading to premature termination of transcription.
As expected for the wild-type, the transcript level of $d s r A$ was very low under organoheterotrophic growth conditions and clearly increased during sulfur oxidation (Fig. 3). The same was observed for the genes $d s r E, d s r C, d s r L, d s r R$ and $d s r S$, indicating that all of the encoded gene products are involved in sulfur oxidation. The mRNA of $d s r E$ was at a similar level under heterotrophic conditions as $d s r A$. Under sulfur-oxidizing conditions, however, the transcript level of $d s r E$ was six times higher than that of $d s r A$ under the same conditions. $d s r C$ and $d s r S$ exhibited significantly higher transcript levels under heterotrophic conditions compared to $d s r A$ and even higher transcript levels when $A$. vinosum was grown on sulfide.

In the mutant $21 \mathrm{D}$, the expression of $d s r A$ was unchanged compared to the wild-type. This was expected, as the $\Omega$ fragment had been inserted in the downstream-located gene $d s r B$. The mRNA level of $d s r E, d s r L$ and $d s r R$ was found to be severely reduced due to this transcriptional block. The low amount of mRNA that was detected despite the block might be due to a spurious transcriptional initiation site located downstream of the interposon. Interestingly, the genes $d s r C$ and $d s r S$ were still expressed at a high level, although the amount of mRNA was reduced

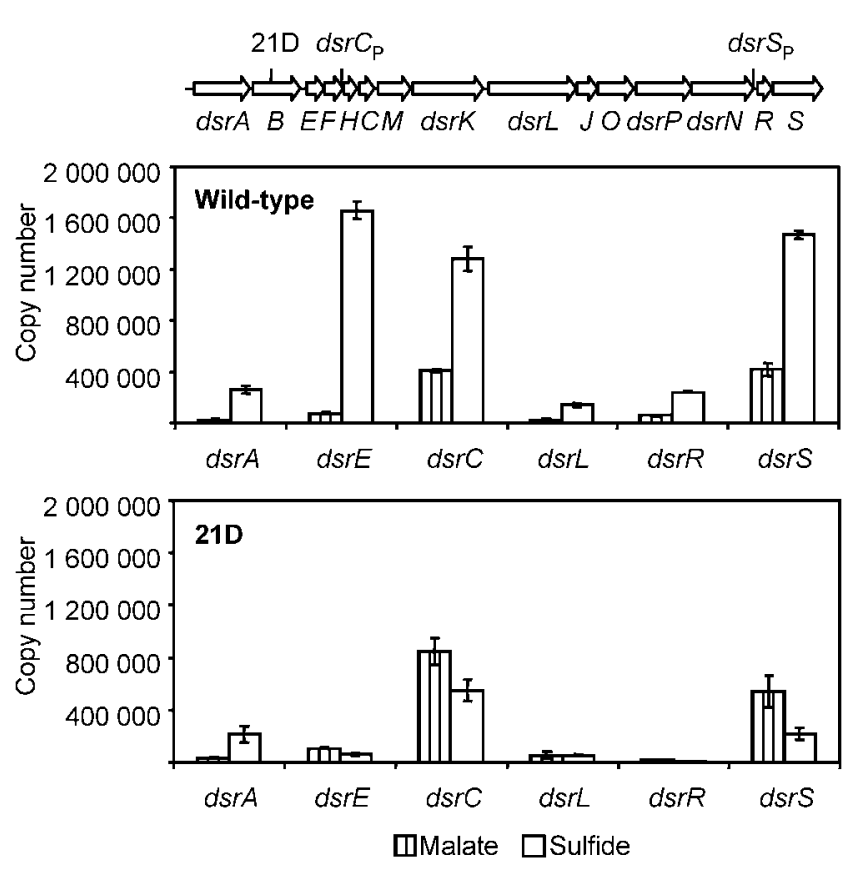

Fig. 3. Expression levels of six dsr genes under photoorganoheterotrophic (malate) and photolithoautotropic (sulfide) conditions determined by real-time RT-PCR. The RNAs were isolated from $A$. vinosum wild-type and the mutant $21 \mathrm{D}$, which carries a transcriptional and translational block in $d s r B$. Samples of $250 \mathrm{ng}$ total RNA were used as template. Quantified external RNA fragments containing the target sequence served as standards. The location of potential secondary promoters for $d s r C$ and $d s r S$ as determined by BPROM and Neural Network Promoter Prediction is indicated. 
under photolithoautotrophic conditions when compared to the level in malate-grown $21 \mathrm{D}$ cells. These findings suggest that $d s r C$ and $d s r S$ are additionally expressed from secondary promoters. Indeed, in silico analyses of the respective upstream gene region using the online tools Neural Network Promoter Prediction and BPROM revealed potential promoter sequences in the region of $d s r F H$ for $d s r C$ and $d s r N R$ for $d s r S$ (Fig. 3). As secondary promoters are usually located in the intergenic region or at the end of a gene (Wek \& Hatfield, 1986) and the $\Omega$ fragment was inserted in the first part of $d s r B$, the high transcript level of $d s r E$ under sulfur-oxidizing conditions in the wild-type is probably due to a higher mRNA stability of the $d s r E$-containing transcript and not to a secondary promoter.

\section{The gene region upstream of the dsr operon does not encode potential regulatory proteins}

In some sulfur-oxidizing bacteria, such as Halorhodospira halophila and Chlorobaculum tepidum [formerly Chlorobium tepidum (Imhoff, 2003)], the genes coding for sulfur-oxidizing ability are clustered, probably due to their acquisition by horizontal transfer (Eisen et al., 2002; Frigaard \& Bryant, 2008; Dahl, 2008; Chan et al., 2008b). In $H$. halophila, putative regulatory proteins are encoded within the gene region that contains the $d s r$ operon (Frigaard \& Dahl, 2009). In an attempt to identify potential regulatory proteins in $A$. vinosum, we cloned and sequenced the region upstream of the $d s r$ operon. We gained $2321 \mathrm{bp}$ of new sequence and identified four new open reading frames, termed orfA, orfB, orfC and orfD (Fig. 4) that are transcribed in the opposite direction from the $d s r$ operon. The main features of the encoded proteins are listed in Table 2. Homologues of OrfA and OrfB are only found in some sulfur-oxidizing bacteria. Homologues of OrfC and OrfD, on the other hand, are quite widespread and are found in sulfur-oxidizing as well as non-sulfuroxidizing bacteria. The importance of OrfB and OrfC for sulfur oxidation was examined by constructing in-frame deletion mutants. Both mutants were not impaired in the oxidation of sulfide to sulfate and exhibited similar sulfur oxidation rates as the wild-type (data not shown). Potential candidates for regulatory proteins were not identified, although the importance of orf $A$ is still uncertain.

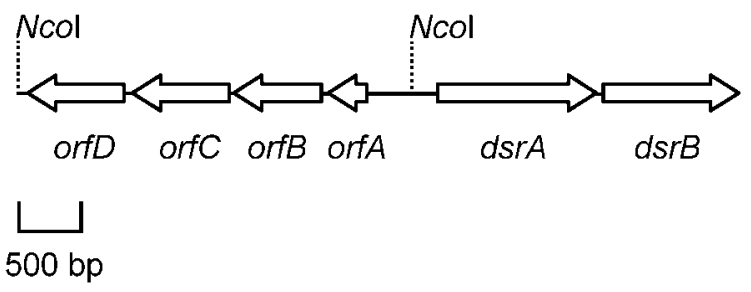

Fig. 4. Schematic representation of the $d s r$ upstream region in $A$. vinosum.

\section{DsrC exhibits DNA-binding properties}

Another likely candidate for a regulatory protein is DsrC. Cort et al. (2008) described a possible helix-turn-helix (HTH) DNA-binding domain, comparable to that of bacterial transcriptional regulatory proteins. We carried out DNA mobility shift assays with the $d s r A$ promoter region and DsrC in order to elucidate this possibility. Recombinant DsrC carrying an N-terminal His-tag was incubated with a $942 \mathrm{bp}$ PCR fragment containing the $d s r A$ promoter region. A $683 \mathrm{bp} \mathrm{PCR-amplified} \mathrm{fragment} \mathrm{of} \mathrm{the}$ kanamycin-resistance gene served as non-specific competitor. The protein-DNA complexes were analysed by agarose gel electrophoresis (Fig. 5a). DsrC bound to the $d s r A$ promoter fragment but not to the competitor DNA. In order to narrow down the DsrC binding site within the promoter region we cleaved the region with EcoRV or XhoI and incubated the fragmented DNA with DsrC (Fig. 5b). Since only one of two restriction fragments in the respective assays was retarded, the other served as an additional internal control for DsrC-specific binding. Comparison of the retarded DNA fragments suggested a DsrC binding site within a 538 bp fragment of the studied 942 bp PCR amplicon.

\section{DISCUSSION}

Here we present an in-depth investigation of $d s r$ gene expression in a phototrophic sulfur-oxidizing organism. Although over the last decade some observations have been made concerning regulation (Pott \& Dahl, 1998; Dahl et al., 2005), a more detailed survey had been lacking until now.

We proved a low expression of several $d s r$ genes under heterotrophic conditions in the absence of reduced sulfur compounds and an increased expression under sulfuroxidizing conditions. This observation agrees with earlier Northern blot analyses that implied an increased $d s r A B$ mRNA level under sulfur-oxidizing conditions (Pott \& Dahl, 1998). Our findings are further corroborated by the results obtained by Dahl et al. (2005), who used Western blot analyses to demonstrate the increased formation of the Dsr proteins DsrE, DsrH, DsrC, DsrK and DsrL under sulfur-oxidizing conditions. On the other hand, the low expression level of sulfite reductase under heterotrophic conditions that we noticed in gene fusion experiments is not in agreement with observations by Schedel et al. (1979). These authors were not able to detect sulfite reductase in malate-grown cells, probably because the enzyme level was below the detection limit. The upregulation of $d s r$ gene expression by reduced sulfur compounds has so far only been described for A. vinosum. In the chemotrophic sulfur oxidizer Thiobacillus denitrificans the $d s r$ genes are highly and most likely constitutively expressed (Beller et al., 2006a, b). As the green sulfur bacterium $C$. tepidum is dependent on sulfide, thiosulfate or sulfur for growth (Chan et al., 2008a), it can be assumed 
Table 2. Features of the proteins encoded upstream of the $d s r$ operon

\begin{tabular}{|c|c|c|c|c|}
\hline Feature & OrfA & OrfB & OrfC & OrfD \\
\hline GenBank accession no. & EER65991.1 & EER65990.1 & EER65989.1 & EER65988.1 \\
\hline Calculated mol. mass (Da) & 9212 & 26307 & 25487 & 25231 \\
\hline Transmembrane helices & None & None & None & None \\
\hline Conserved domains & None & None & $\begin{array}{l}\text { TIGR02807: CRISPR-associated } \\
\text { protein, Cas6-related }{ }^{\star}\end{array}$ & $\begin{array}{l}\text { COG1392: phosphate } \\
\text { transport regulator }\end{array}$ \\
\hline Further comments & Function unclear & $\begin{array}{l}\text { orf } B \text { homologues are } \\
\text { encoded next to Trp } \\
\text { biosynthesis genes }\end{array}$ & $\begin{array}{l}\text { Last hydrophobic residue of Cas6 } \\
\text { motif exchanged for Cys; orfC } \\
\text { homologues do not occur in the } \\
\text { vicinity of CRISPRs }\end{array}$ & $\begin{array}{l}\text { Encoded adjacent to } \\
\text { phosphate } \\
\text { transporter } \\
(\text { EER65987.1) }\end{array}$ \\
\hline
\end{tabular}

${ }^{*}$ CRISPR (clustered regularly interspaced short palindromic repeats) and their associated proteins (Cas) represent a defence mechanism against invasion of phages and plasmids.

that $d s r$ genes are constitutively expressed in this organism as well.

Time-course experiments showed that the expression of $d s r A$ was not enhanced before the vast majority of sulfide had been metabolized and sulfur globules had been formed. Therefore, sulfide is most likely not the direct inducing factor of $d s r$ gene expression. Nevertheless, experiments with varying sulfide concentrations showed the expression level to be dependent on the strength of the inducing signal. Apparently, the expression can be modified according to demand.

Sulfate concentration increased concurrently with the $\beta$ galactosidase activities, implicating the oxidation of stored sulfur to sulfite as the rate-limiting step in the oxidation of sulfur to sulfate. This corresponds with the fact that sulfite is hardly detected during sulfur oxidation in A. vinosum

(a)

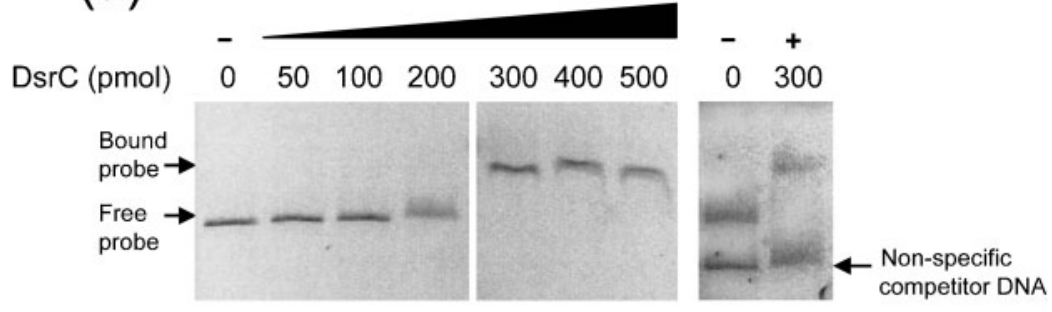

(b)
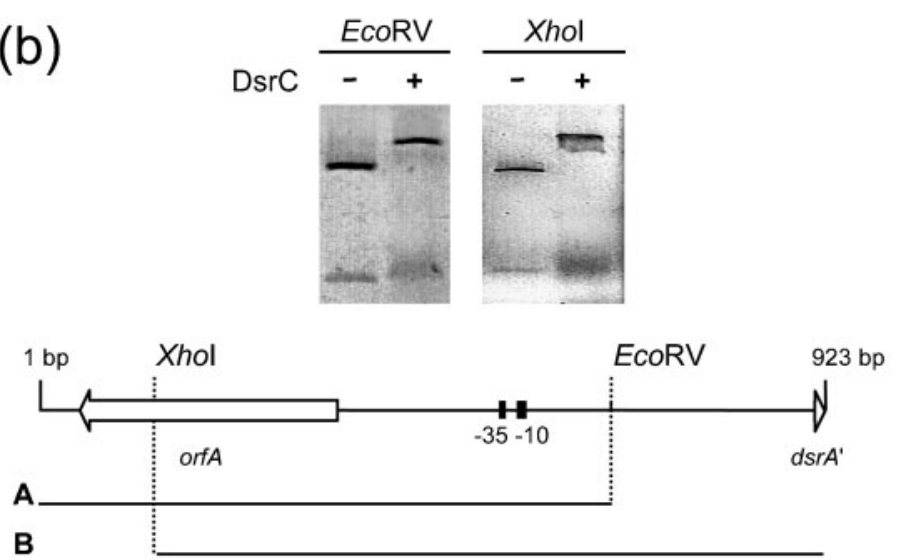

Fig. 5. DNA mobility shift assay of DsrC binding to the $d s r A$ promoter region. (a) The 942 bp promoter region was mixed with 0500 pmol recombinant DsrC. A fragment of the kanamycin-resistance gene served as nonspecific competitor and was incubated together with the dsr promoter region with (+) and without (-) 300 pmol DsrC. (b) Narrowing down the DsrC binding site within the $d s r$ promoter region. The subfragments of the promoter region were achieved by digestion with the indicated restriction enzymes. The DNA fragments were incubated with or without 300 pmol DsrC prior to agarose gel electrophoresis. DNA fragments retarded by DsrC are marked ( $A$ and $B)$. 
(Steudel et al., 1990; Dahl, 1996; Dahl et al., 2008). Considering the high reactivity and toxicity of free sulfite in the cytoplasm, it is not surprising that the organism protects itself by a fast turnover.

The mechanism of sulfite oxidation in phototrophic sulfuroxidizing bacteria is still unknown, although several candidates have been identified (Frigaard \& Dahl, 2009). For a number of chemo- and photolithotrophic sulfur oxidizers (e.g. T. denitrificans, A. vinosum, C. tepidum) the simultaneous occurrence of two sulfite-oxidizing pathways has been observed (Dahl, 1996; Kappler \& Dahl, 2001; Frigaard \& Dahl, 2009). The possession of an additional periplasmically located pathway might serve the organism in the oxidation of externally added sulfite (Kappler \& Dahl, 2001). This could explain why externally added sulfite did not inhibit the expression of the $d s r$ genes.

The alternative electron donor malate had no effect on the expression of $d s r A$. It had been observed earlier that the reduced sulfur compound thiosulfate is metabolized in the presence of an organic carbon and electron donor, like pyruvate or acetate in A. vinosum (Hurlbert \& Lascelles, 1963; Hurlbert, 1968). Moreover, thiosulfate exerts a repressive effect on the utilization of pyruvate. The synthesis of ribulose-1,5-bisphosphate carboxylase, which catalyses the main $\mathrm{CO}_{2}$ fixation reaction in Chromatiaceae (Sahl \& Trüper, 1977), is inhibited by the presence of an organic compound (Fuller et al., 1961) but the repression is not complete and a residual activity can be detected, depending on the presence of reduced sulfur compounds (Hurlbert \& Lascelles, 1963). Therefore, pure photoheterotrophy apparently only occurs when reduced sulfur compounds are limited. These observations suggest a preferential utilization of reduced sulfur compounds over organic compounds as electron donors.

We postulate additional secondary promoters involved in the expression of $d s r C$ and $d s r S$. This conclusion is corroborated by the differential regulation of the genes in other organisms. In several sulfate-reducing prokaryotes, such as Desulfovibrio vulgaris Hildenborough, the $d s r C$ gene is located separately from $d s r A B$ and the expression of these genes is not co-ordinately regulated (KarkhoffSchweizer et al., 1993). dsrS homologues are found in several sulfur-oxidizing bacteria, such as $T$. denitrificans and 'Candidatus Vesicomyosocius okutanii', but only in $A$. vinosum is dsrS part of the dsr operon (Dahl et al., 2005; Sander et al., 2006). Moreover, Northern blot experiments showed a $0.9 \mathrm{~kb}$ mRNA detectable by a $d s r C$ probe that was present in the 21D mutant (Pott \& Dahl, 1998). The authors suggested a secondary promoter for $d s r C$ probably located in $d s r F$ (Cort et al., 2008). Furthermore, in silico analyses revealed potential promoter sequences in the respective upstream regions of $d s r C$ and $d s r S$. We noticed an increase of the $d s r C$ and $d s r S$ mRNA level in the wildtype and a reduction of the mRNA level in the 21D mutant, indicating that the regulatory signals of $d s r C_{\mathrm{P}}$ and $d s r S_{\mathrm{P}}$ appear to be different from those of $d s r A_{\mathrm{P}}$, as the expression of $d s r A$ in the mutant was unchanged from wild-type expression.

The importance of the differential regulation of $d s r S$ is unclear. The increased mRNA level of $d s r S$ under sulfuroxidizing conditions clearly implies that DsrS plays a role in the oxidation of sulfur in $A$. vinosum, although the presence of $d s r S$ is not required for sulfur oxidation, as many sulfur-oxidizing bacteria like C. tepidum and $H$. halophila do not contain a copy of the gene (Sander et al., 2006; Frigaard \& Dahl, 2009). DsrS exhibits no significant homologies to proteins of known function (Dahl et al., 2005) and nothing can be said concerning a probable function of DsrS at present.

$d s r C$, on the other hand, is part of the core set of $d s r$ genes present in all sulfur-oxidizing bacteria and sulfate-reducing prokaryotes (Sander et al., 2006; Frigaard \& Dahl, 2009). A high transcript level of $d s r C$ has also been noted in $T$. denitrificans (Beller et al., 2006a, b) and D. vulgaris (Haveman et al., 2003). DsrC is highly similar to TusE, a protein involved in the sulfur relay mechanism leading to biosynthesis of thiouridine at the wobble position of tRNA (Numata et al., 2006; Cort et al., 2008). DsrC from Desulfovibrio vulgaris interacts closely with DsrAB: The highly conserved C-terminal arm of D. vulgaris DsrC has been shown to be able to reach the active site of the reductase (Oliveira et al., 2008). Based on these findings it has been proposed that DsrC from A. vinosum is part of a substrate-delivery system for the reverse sulfite reductase (Cort et al., 2008; Dahl et al., 2008). Interestingly, DsrEFH, the protein complex encoded immediately upstream of $d s r C$, shows high similarities to TusBCD, the sulfur donor of TusE (Dahl et al., 2008). The reason for the differential regulation of $d s r C$ might therefore be found in the function of DsrC as co-substrate for sulfite reductase. The continuous presence of DsrC even under non-sulfuroxidizing conditions might be advantageous because it guarantees a fast turnover rate. The surprisingly high transcription rate of $d s r E$ under sulfur-oxidizing conditions might be due to the need of the organism to quickly build up enough DsrEFH to ensure a fast sulfur transfer to DsrC.

We were able to confirm the proposed DNA-binding ability of DsrC (Cort et al., 2008) by DNA mobility shift assays. DsrC binds specifically to a DNA fragment framed by XhoI and EcoRV restriction sites (nucleotides -774 to -236 upstream of $d s r A$ ). An analysis of the sequence with the Neural Network Promoter Prediction and BPROM online tools revealed a potential promoter within the $538 \mathrm{bp}$ fragment, starting 369 nucleotides upstream of the $d s r A$ start codon (Fig. 5b). Furthermore, in silico analysis revealed several noticeable sequence patterns (palindromic and reverse repeats) within this DNA fragment. Especially conspicuous is a nearly perfect $20 \mathrm{bp}$ palindrome, AAACTGTAATATTAGAGTTT, that is situated immediately upstream of the potential promoter. It starts 391 nucleotides upstream of the $d s r A$ gene. Such motifs with pronounced dyad symmetry are typically bound by 
symmetrical transcription factor homodimers where each subunit binds to one half of the motif via a helix-turnhelix motif. It is interesting to note in this respect that DsrC has been reported to form homodimers (Cort et al., 2008). The length of the potential transcription factor recognition site and its immediate vicinity to the proposed -35 region of the promoter are reminiscent of the situation found for a number of well-characterized transcription factors of the LuxR family, e.g. TraR, which regulates genes of the tumour-inducing plasmid of Agrobacterium tumefaciens (White \& Winans, 2007).

In summary, our findings suggest a second function for DsrC as a regulatory protein. The utilization of the same protein for two distinct functions has already been described for several polypeptides. One well-documented example is PutA from E. coli. This protein catalyses the two-step oxidation of proline to glutamate and serves as a transcriptional repressor of the proline utilization $(p u t)$ genes (Lee et al., 2003).

Several copies of putative $d s r C$ homologues are found in the genomes of T. denitrificans (Beller et al., 2006a) and A. vinosum. In $T$. denitrificans only the product of the $d s r C$ gene, which is part of the $d s r$ operon, contains the two C-terminal conserved cysteine residues. The other DsrC candidates contain only one or none of these cysteine residues, making a participation in sulfur oxidation unlikely. A. vinosum possesses five $d s r C$ homologues, the products of two of which contain both cysteine residues, the $d s r C$ copy in the $d s r$ operon and AlvinDRAFT_0109 (ZP_04772576.1). The latter is not encoded in the vicinity of sulfur oxidation-related genes. The DsrC homologues with one conserved cysteine residue corresponding to Cys111 of A. vinosum might be TusE homologues and therefore be involved in thiouridine modification, but the function of the other DsrC candidates is unclear. The $d s r C$ copies of $T$. denitrificans show a wide variability in their expression pattern (Beller et al., 2006b). While the $\mathrm{C}$-terminus with its conserved cysteine residues is important for the function as substrate carrier, the overall DsrC fold might serve another, possibly regulatory function which is preserved in these other DsrC-like proteins. DsrC exhibiting a second function would also explain why neither the secondary promoter $d s r C_{\mathrm{P}}$, located in $d s r F$, nor $d s r C$ itself can be stably deleted from the A. vinosum genome (Cort et al., 2008). Both deletion mutants could not be maintained in liquid culture, neither on media containing malate nor in the presence of reduced sulfur compounds (Cort et al., 2008; Dahl et al., 2008). Comparable phenotypes were not observed for other $d s r$ deletion mutants, including a $d s r E$-deficient mutant. The severity of this phenotype is therefore not in accordance with the previous assumption that DsrC has only a single function, i.e. to act as part of a substrate-delivery system.

The additional function of DsrC as a regulatory protein suggests another reason for the differential regulation of $d s r C$. The protein may be constitutively expressed to provide a basal level, so that transcription can quickly be induced in changing environmental conditions. Such a mechanism has already been reported for Salmonella typhimurium EutR, the transcriptional activator of the eut operon. The latter encodes ethanolamine-utilization genes. EutR is expressed from a weak constitutive promoter within the operon as well as from the main promoter. The expression of eutR increases when the expression of the operon is induced, creating a positive feedback loop that is necessary for maximal operon expression (Roof \& Roth, 1992).

\section{ACKNOWLEDGEMENTS}

This work was supported by grants Da351/3-4 and 3-5 from the Deutsche Forschungsgemeinschaft (DFG). We thank Bernd Masepohl for his helpful tips concerning gene fusion and Bettina Franz for insightful discussions.

\section{REFERENCES}

Beller, H. R., Chain, P. S. G., Letain, T. E., Chakicherla, A., Larimer, F. W., Richardson, P. M., Coleman, M. A., Wood, A. P. \& Kelly, D. P. (2006a). The genome sequence of the obligately chemolithoautotrophic, facultatively anaerobic bacterium Thiobacillus denitrificans. J Bacteriol 188, 1473-1488.

Beller, H. R., Letain, T. E., Chakicherla, A., Kane, S. R., Legler, T. C. \& Coleman, M. A. (2006b). Whole-genome transcriptional analysis of chemolithoautotrophic thiosulfate oxidation by Thiobacillus denitrificans under aerobic versus denitrifying conditions. J Bacteriol 188, 7005-7015.

Bradford, M. M. (1976). A rapid and sensitive method for the quantitation of microgram quantities of protein utilizing the principle of protein-dye binding. Anal Biochem 72, 248-254.

Chan, L.-K., Morgan-Kiss, R. \& Hanson, T. E. (2008a). Sulfur oxidation in Chlorobium tepidum (syn. Chlorobaculum tepidum): genetic and proteomic analyses. In Microbial Sulfur Metabolism, pp. 117-126. Edited by C. Dahl \& C. G. Friedrich. Heidelberg \& Berlin: Springer.

Chan, L.-K., Morgan-Kiss, R. \& Hanson, T. E. (2008b). Genetic and proteomic studies of sulfur oxidation in Chlorobium tepidum (syn. Chlorobaculum tepidum). In Sulfur Metabolism in Phototrophic Organisms, pp. 357-373. Edited by R. Hell, C. Dahl, D. B. Knaff \& T. Leustek. Dordrecht: Springer.

Cort, J. R., Mariappan, S. V. S., Kim, C.-Y., Park, M. S., Peat, T. S., Waldo, G. S., Terwilliger, T. C. \& Kennedy, M. A. (2001). Solution structure of Pyrobaculum aerophilum DsrC, an archaeal homologue of the gamma subunit of dissimilatory sulfite reductase. Eur J Biochem 268, 5842-5850.

Cort, J. R., Selan, U., Schulte, A., Grimm, F., Kennedy, M. A. \& Dahl, C. (2008). Allochromatium vinosum DsrC: solution-state NMR structure, redox properties, and interaction with DsrEFH, a protein essential for purple sulfur bacterial sulfur oxidation. J Mol Biol 382, 692-707.

Dahl, C. (1996). Insertional gene inactivation in a phototrophic sulphur bacterium: APS-reductase-deficient mutants of Chromatium vinosum. Microbiology 142, 3363-3372.

Dahl, C. (2008). Inorganic sulfur compounds as electron donors in purple sulfur bacteria. In Sulfur Metabolism in Phototrophic 
Organisms, pp. 289-317. Edited by R. Hell, C. Dahl, D. B. Knaff \& T. Leustek. Dordrecht: Springer.

Dahl, C. \& Prange, A. (2006). Bacterial sulfur globules: occurrence, structure and metabolism. In Inclusions in Prokaryotes, pp. 21-51. Edited by J. M. Shively. Heidelberg: Springer.

Dahl, C., Engels, S., Pott-Sperling, A. S., Schulte, A., Sander, J., Lübbe, Y., Deuster, O. \& Brune, D. C. (2005). Novel genes of the $d s r$ gene cluster and evidence for close interaction of Dsr proteins during sulfur oxidation in the phototrophic sulfur bacterium Allochromatium vinosum. J Bacteriol 187, 1392-1404.

Dahl, C., Schulte, A., Stockdreher, Y., Hong, C., Grimm, F., Sander, J., Kim, R., Kim, S.-H. \& Shin, D. H. (2008). Structural and molecular genetic insight into a widespread sulfur oxidation pathway. J Mol Biol 384, 1287-1300.

Eisen, J. A., Nelson, K. E., Paulsen, I. T., Heidelberg, J. F., Wu, M., Dodson, R. J., Deboy, R., Gwinn, M. L., Nelson, W. C. \& other authors (2002). The complete genome sequence of Chlorobium tepidum TLS, a photosynthetic, anaerobic, green-sulfur bacterium. Proc Natl Acad Sci U S A 99, 9509-9514.

Fey, A., Eichler, S., Flavier, S., Christen, R., Höfle, M. G. \& Guzmán, C. A. (2004). Establishment of a real-time PCR-based approach for accurate quantification of bacterial RNA targets in water, using Salmonella as a model organism. Appl Environ Microbiol 70, 36183623.

Frigaard, N.-U. \& Bryant, D. A. (2008). Genomic insights into the sulfur metabolism of phototrophic green sulfur bacteria. In Sulfur Metabolism in Phototrophic Organisms, pp. 337-355. Edited by R. Hell, C. Dahl, D. B. Knaff \& T. Leustek. Dordrecht: Springer.

Frigaard, N.-U. \& Dahl, C. (2009). Sulfur metabolism in phototrophic sulfur bacteria. Adv Microb Physiol 54, 103-200.

Fuller, R. C., Smillie, R. M., Sisler, E. C. \& Kronberg, H. L. (1961). Carbon metabolism in Chromatium. J Biol Chem 236, 2140-2149.

Grimm, F., Franz, B. \& Dahl, C. (2008). Thiosulfate and sulfur oxidation in purple sulfur bacteria. In Microbial Sulfur Metabolism, pp. 101-116. Edited by C. Dahl \& C. G. Friedrich. Berlin \& Heidelberg: Springer.

Haveman, S. A., Brunelle, V., Voordouw, J. K., Voordouw, G., Heidelberg, J. F. \& Rabus, R. (2003). Gene expression analysis of energy metabolism mutants of Desulfovibrio vulgaris Hildenborough indicates an important role for alcohol dehydrogenase. J Bacteriol 185, 4345-4353.

Hübner, P., Willison, J. C., Vignais, P. \& Bickle, T. A. (1991). Expression of regulatory nif genes in Rhodobacter capsulatus. J Bacteriol 173, 2993-2999.

Hurlbert, R. E. (1968). Effect of thiol-binding reagents on the metabolism of Chromatium D. J Bacteriol 95, 1706-1712.

Hurlbert, R. E. \& Lascelles, J. (1963). Ribulose diphosphate carboxylase in Thiorhodaceae. J Gen Microbiol 33, 445-458.

Imhoff, J. F. (2003). Phylogenetic taxonomy of the family Chlorobiaceae on the basis of $16 \mathrm{~S}$ rRNA and fmo (FennaMatthews-Olson protein) gene sequences. Int J Syst Evol Microbiol 53, 941-951.

Kappler, U. \& Dahl, C. (2001). Enzymology and molecular biology of prokaryotic sulfite oxidation. FEMS Microbiol Lett 203, 1-9.

Karkhoff-Schweizer, R. R., Bruschi, M. \& Voordouw, G. (1993). Expression of the $\gamma$-subunit gene of desulfoviridin-type dissimilatory sulfite reductase and of the $\alpha$ - and $\beta$-subunit genes is not coordinately regulated. Eur J Biochem 211, 501-507.

Lee, Y.-H., Nadaraia, S., Gu, D., Becker, D. F. \& Tanner, J. J. (2003). Structure of the proline dehydrogenase domain of the multifunctional PutA flavoprotein. Nat Struct Biol 10, 109-114.
Loy, A., Duller, S., Baranyi, C., Mußmann, M., Ott, J., Sharon, I., Béjà, O., Le Paslier, D., Dahl, C. \& Wagner, M. (2009). Reverse dissimilatory sulfite reductase as phylogenetic marker for a subgroup of sulfur-oxidizing prokaryotes. Environ Microbiol 11, 289-299.

Lübbe, Y. J., Youn, H.-S., Timkovich, R. \& Dahl, C. (2006). Siro(haem)amide in Allochromatium vinosum and relevance of DsrL and DsrN, a homolog of cobyrinic acid $a, c$-diamide synthase, for sulphur oxidation. FEMS Microbiol Lett 261, 194-202.

Miller, J. H. (1972). Assay of $\beta$-galactosidase. In Experiments in Molecular Genetics, pp. 352-355. Edited by J. H. Miller. Cold Spring Harbor, NY: Cold Spring Harbor Laboratory.

Numata, T., Fukai, S., Ikeuchi, Y., Suzuki, T. \& Nureki, O. (2006). Structural basis for sulfur relay to RNA mediated by heterohexameric TusBCD complex. Structure 14, 357-366.

Oliveira, T. F., Vonrhein, C., Matia, P. M., Venceslau, S. S., Pereira, I. A. C. \& Archer, M. (2008). The crystal structure of Desulfovibrio vulgaris dissimilatory sulfite reductase bound to DsrC provides novel insights into the mechanism of sulfate respiration. J Biol Chem 283, 34141-34149.

Pattaragulwanit, K. \& Dahl, C. (1995). Development of a genetic system for a purple sulfur bacterium: conjugative plasmid transfer in Chromatium vinosum. Arch Microbiol 164, 217-222.

Pfennig, N. \& Trüper, H. G. (1989). Anoxygenic phototrophic bacteria. In Bergey's Manual of Systematic Bacteriology, vol. 3, pp. 1635-1653. Edited by J. T. Staley, M. P. Bryant, N. Pfennig \& J. G. Holt. Baltimore: Williams \& Wilkins.

Pott, A. S. \& Dahl, C. (1998). Sirohaem sulfite reductase and other proteins encoded in the $d s r$ locus of Chromatium vinosum are involved in the oxidation of intracellular sulfur. Microbiology 144, 1881-1894.

Prange, A., Engelhardt, H., Trüper, H. G. \& Dahl, C. (2004). The role of the sulfur globule proteins of Allochromatium vinosum: mutagenesis of the sulfur globule protein genes and expression studies by realtime RT PCR. Arch Microbiol 182, 165-174.

Roof, D. M. \& Roth, J. R. (1992). Autogenous regulation of ethanolamine utilization by a transcriptional activator of the eut operon in Salmonella typhimurium. J Bacteriol 174, 6634-6643.

Sahl, H. G. \& Trüper, H. G. (1977). Enzymes of $\mathrm{CO}_{2}$ fixation in Chromatiaceae. FEMS Microbiol Lett 2, 129-132.

Sander, J. \& Dahl, C. (2009). Metabolism of inorganic sulfur compounds in purple bacteria. In The Purple Phototrophic Bacteria, pp. 595-622. Edited by C. N. Hunter, F. Daldal, M. C. Thurnauer \& J. T. Beatty. Dordrecht: Springer.

Sander, J., Engels-Schwarzlose, S. \& Dahl, C. (2006). Importance of the DsrMKJOP complex for sulfur oxidation in Allochromatium vinosum and phylogenetic analysis of related complexes in other prokaryotes. Arch Microbiol 186, 357-366.

Schäfer, A., Tauch, A., Jäger, W., Kalinowski, J., Thierbach, G. \& Pühler, A. (1994). Small mobilizable multi-purpose cloning vectors derived from the Escherichia coli plasmids pK18 and pK19: selection of defined deletions in the chromosome of Corynebacterium glutamicum. Gene 145, 69-73.

Schedel, M. \& Trüper, H. G. (1979). Purification of Thiobacillus denitrificans siroheme sulfite reductase and investigation of some molecular and catalytic properties. Biochim Biophys Acta 568, 454467.

Schedel, M., Vanselow, M. \& Trüper, H. G. (1979). Siroheme sulfite reductase isolated from Chromatium vinosum. Purification and investigation of some of its molecular and catalytic properties. Arch Microbiol 121, 29-36. 
Steudel, R., Holdt, G., Visscher, P. T. \& van Gemerden, H. (1990). Search for polythionates in cultures of Chromatium vinosum after sulfide incubation. Arch Microbiol 153, 432-437.

Wek, R. C. \& Hatfield, G. W. (1986). Examination of the internal promoter, $\mathrm{P}_{\mathrm{E}}$, in the ilvGMEDA operon of E. coli K-12. Nucleic Acids Res 14, 2763-2777.
White, C. E. \& Winans, S. C. (2007). The quorum-sensing transcription factor TraR decodes its DNA binding site by direct contacts with DNA bases and by detection of DNA flexibility. Mol Microbiol 64, 245-256.

Edited by: G. Muyzer 